WELCOMING ADDRESSES and AFTER-DINNER SPEECH 


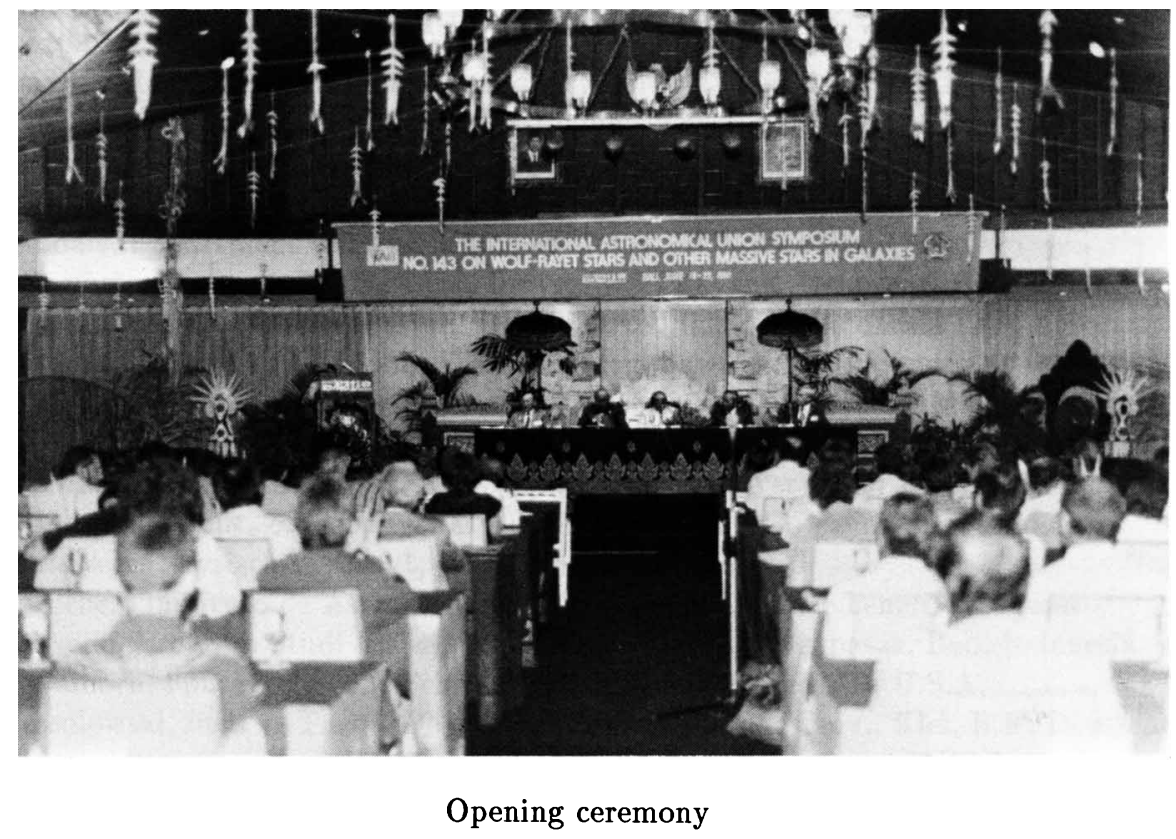




\title{
SAMBUTAN KETUA LOCAL ORGANIZING COMMITTEE
}

\author{
Bapak Gubernur, Prof. Oka, Yth., \\ Bapak Direktur Jenderal Pendidikan Tinggi, Yth., \\ Hadirin Yth.,
}

Perkenankanlah kami melaporkan bahwa kami bersyukur dan bergembira, pertemuan yang telah direncanakan semenjak 2 tahun lalu, pada hari ini dapat terlaksana. Semenjak General Assembly International Astronomical Union di Baltimore pada bulan Agustus 1988 menyetujui tema dan susunan anggota Scientific Organizing Commitee, komunikasi antara anggota SOC yang tersebar di 13 negara tampak menjadi lebih intensif untuk memilih tema dan subtema. Pemilihan subtema itu sangat penting karena pertemuan ini berharap dapat:

1. memberikan hasil pengamatan dan interpretasi teoritis tentang kelahiran dan evolusi bintang Wolf-Rayet dan bintang masif, dari fasilitas pengamatan landas bumi; landas layang maupun dari satelit.

2. menentukan masalah strategis dan terpadu untuk mengetahui sumbangan bintang terhadap evolusi galaksi; serta evolusi bintang berat.

Peserta pertemuan ini berjumlah 118 astronom dari 18 negara, akan membahas 20 buah invited reviews, 36 buah invited contributions. Sayang sekali karena keterbatasan waktu memaksa kami mempergunakan metode penyajian - yang tidak kalah penting "poster session" sebanyak 73 karya ilmiah. Sebagian besar sumbangan ilmiah poster in merupakan hasil pengamatan dan pengembangan teori dalam tempo 12 bulan terakhir ini.

Dalam merealisasikan pertemuan ini kami telah memperoleh banyak dukungan moril dari Bapak Mendikbud, Menparpostel, dan bantuan materil dari berbagai pihak.

Pada bulan Oktober 1988 kami menghadap Bapak Gubernur Bali, Prof. Oka, dan Bapak Rektor Universitas Udayana, Prof. Adnyana. Dari pertemuan awal itu kami merasa memperoleh dorongan untuk maju mempersiapkan pertemuan ini di Denpasar. Kami hendak menyampaikan banyak terima kasih kepada Pemda yang telah memberikan dukungan moril selama ini.

Secara operasional Local Organizing Committee, yang terdiri dari 7 orang dari 5 instansi bekerja dibawah naungan 2 buah universitas: Udayana dan ITB dan Direktur Jendral Pendidikan Tinggi. Kehangatan naungan sayap mereka membuat LOC lebih bergairah untuk membuat pertemuan ini berharga bagi ilmu pengetahuan.

Dari buku "Biru" dapat dilihat bahwa pertemuan ini dapat terselenggara berkat sentuhan tangan banyak pihak. Tanpa itu kami, LOC dan SOC, hanya seperti kertas saja tanpa daya. Kami mohon maaf. Karena keterbatasan waktu pagi ini kami tidak dapat menyebut satu persatu nama pendukung pertemuan ini, namun rekaman tertulis dalam "buku program" - yang juga merupakan prakata "Proceedings" kami nanti - adalah pengejawantahan rasa terima kasih kepada semua pihak yang telah ikut menyelenggarakan pertemuan ini. Namun begitu, kami mohon ijin untuk menyebut kerjasama KNI-Unesco, Departemen Luar Negeri, LIPI dan Bappenas serta Garuda Indonesia Airlines, yang benarbenar telah merupakan rantai vital bagi terselenggaranya pertemuan ini.

Akhirnya, kami hendak menyampaikan banyak terima kasih kepada Bapak Alfons D. Viera, G.M. Hotel Bali Beach, beserta staf yang telah banyak memberikan kemudahan bagi kami. Dalam pada itu sudah sepantasnya kalau kami mohon maaf kepada semua pihak atas segala kekurangan L.O.C. dalam penyelenggara ini.

Hadirin yth., ijinkan saya sekarang menyampaikan pesan dalam bahasa Ingris, untuk kepentingan rekan yang tidak paham bahasa Indonesia dan untuk memberikan rasa international pada pertemuan ini.

K. A. van der Hucht and B. Hidayat (eds.),

Wolf-Rayet Stars and Interrelations with Other Massive Stars in Galaxies, 3-4.

(C) 1991 IAU. Printed in the Netherlands. 
Distinguished guests, colleagues and participants,

I have just reported to the Minister of Education and Culture what we are going to talk about, discuss and, hopefully, solve during the next five days here on the island of gods, goddesses and demons. It is not my intention to repeat what I have said about our business, but, instead, I would like to extend to you all a few words on behalf of the Local Organizing Committee and all our Indonesian friends.

Dr. van der Hucht, the Chairman of SOC, who chose the date of this meeting may have a 6 th sense. The calendar indicates that today is June 18th, 1990. This is all right, we all know it. But the Balinese have many different systems of time designation. According to their calendrical system today is the 25th week of Caka 1912, or Sasih Sadha Ngunya Karo, or the 28th day of Mintuna Rasi, etc., which all coincides with the best time to sow seeds. Everybody, man, woman and hermaphrodites, are promised success if they plant on this day. I happened to discover the significance of this day only two weeks ago when I consulted an old-time Bali calendar. In this frame of mind I wish you all success in your deliberations. We will plant good seeds, which we hope will bear good useful fruit in the decade of the 90's and beyond.

We would like to wish all participants, first of all, enjoy your scientific topics and our meeting venue, and naturally, your short stay here in Bali, Indonesia. If I stress the word "meeting" in the first place, I am really not exaggerating, because the natural surroundings of this hotel are a really great attraction and distraction which might lure you all to forget the prime business of coming to Bali.

Now please forgive our shortcomings and omissions. You know our word-processors and type writers have occasional lapses when typing English or foreign names. So there may be some spelling mistakes. But, anyway please ask if there is something which is not clear. Our desk and office, respectively on the first and third floor (rm 304) are open to you all time.

We are really delighted to welcome you all here. Bali is well-known for its cosmical and cosmogonical perception, which is interwoven with day-to-day affairs. This is reflected in the smiling, contended faces of the Balinese people and by their constant observation of their religious duties which blesses their lives. The rolling green of the countrysides, towered by the puras for offerings, are manifestations of their harmonious life with the nature, which, I hope, you may have a chance to experience.

Saudara - I am fond of this word as it brings a sense of a brotherhood -, Selamat Datang di Indonesia dan Selamat Bekerja.

Bambang Hidayat 